\title{
2 Evolutionary consequences of dispersal ability in cactus-feeding insects
}

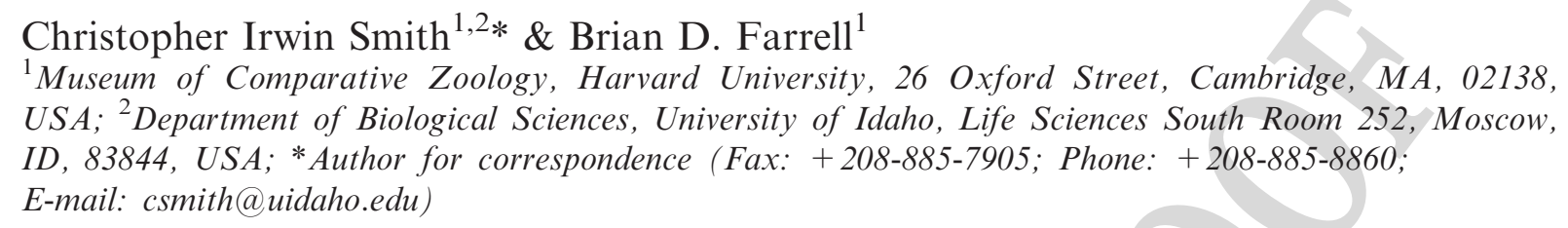

9 Received 2 April 2005 Accepted 7 July 2005

Key words: cerambycidae, coenopoeus, flightlessness, gene flow, habitat patchiness, moneilema

\section{Abstract}

13 Although gene flow is an important determinant of evolutionary change, the role of ecological factors such

14 as specialization in determining migration and gene flow has rarely been explored empirically. To examine

15 the consequences of dispersal ability and habitat patchiness on gene flow, migration rates were compared in

16 three cactophagous Longhorn beetles using coalescent analyses of mtDNA sequences. Analyses of

17 covariance were used to identify the roles of dispersal ability and habitat distribution in determining

18 migration patterns. Dispersal ability was a highly significant predictor of gene flow $(p<0.001)$, and was

19 more important than any other factor. These findings predict that dispersal ability may be an import factor

20 shaping both microevolutionary and macroevolutionary patterns; this prediction is borne out by

21 comparisons of species diversity in cactus-feeding groups.

\section{Introduction}

Gene flow is a fundamental determinant of the rate and trajectory of genetic diversification in sexual organisms. Levels of gene flow between populations influence the degree to which isolated demes will either share a common evolutionary trajectory, or will diverge over time through genetic drift and natural selection (Wright, 1943; Wright, 1978; Slatkin, 1985; Slatkin, 1987). Cessation of gene flow is therefore necessary for speciation to proceed (Mayr, 1942), and many biologists consider genetic isolation to be diagnostic of species status (Mayr, 1942; Mayr, 1963; Templeton, 2001). Conversely, sustained gene flow between demes may either allow beneficial mutations to spread, or may prevent peripheral populations from adapting to local environments at the edge of a species' range (Dobzhansky, 1937; Futuyma, 1987; Thompson \& Cunningham, 2002).

Elucidating the mechanisms that either promote or impede gene flow between demes is therefore essential to explaining both the evolutionary process and the diversification of sexual organisms. The distribution of populations (Roderick, 1996; Young, Boyle \& Brown, 1996), dispersal ability (Peterson \& Denno, 1998), and geographic barriers to dispersal (Avise, 1994) represent some of the most obvious factors that may determine rates of gene exchange between populations, but other ecological factors such as host specificity, mutualistic relationships, and competition may also play equally important roles. However, despite the importance of migration and gene flow in the evolutionary process, the role of ecological factors in governing rates of gene flow between populations has received little empirical study. Although there has been increasing interest in how the distribution of genetic variation may influence ecological phenomena (Antonovics, 1992; Collins, 2003; Morin, 2003), very little attention has been paid to how ecological processes shape population genetic patterns.

\begin{tabular}{|l|lll|}
\hline & Journal : GENE & Dispatch : 27-7-2005 & Pages : 12 \\
CMS No. : DO00020714 & $\square$ LE & $\square$ TYPESET \\
MS Code: GENE 104R1 & $\nabla$ CP & $\square$ DISK \\
\hline
\end{tabular}


Phytophagous insects present an appropriate venue in which to explore how ecological factors affect levels of gene exchange and population structure. Within a group as species rich and diverse in their natural history as the Insecta, it may be possible to identify multiple, evolutionarily distinct groups that share common ecological characteristics and to examine the consequences of those characteristics for population structure. Also, because the vast majority of phytophagous insects feed on a limited number of plant species (Strong et al., 1984), they have discreet, and easily definable potential habitats.

Much previous work has focused on the pivotal role that specialization may play in determining population structure and migration rates in phytophagous insects. It has been suggested, for example, that insects specialized on one or a few hosts may have smaller, and more patchily distributed populations with inherently lower rates of gene flow between populations, and that this may in turn have promoted the diversification of specialist lineages (Farrell \& Mitter, 1994; Futuyma \& Moreno, 1988; Farrell, 1998).

However, the current empirical evidence regarding the effect of specialization on gene flow and population structure is equivocal. A study of carabid ground beetles found that populations of montane species, with consequently patchy distributions, were generally isolated from one another, and had lower levels of migration between populations than lowland species in more continuous habitats (Liebherr, 1988). However a review of 43 previous studies of gene flow in phytophagous insects found no significant differences in the degree of isolation by distance between monophagous, oligophagous, and polyphagous insects (Peterson \& Denno, 1998). Additionally, whereas Liebherr's (1988) study found no significant correlation between flight wing development and gene flow, the latter study found that dispersal ability, rather than specialization, or distribution, was a much more important determinant of population structure (Peterson \& Denno, 1998). Finally, although a comparison of a comparison of two sister species of bark beetles that differed in diet breadth (Kelley et al., 2000) found that the specialist had lower levels of gene flow between populations, this study did not consider whether the species differed in dispersal ability.
The ambiguity of the existing empirical evidence is heightened by the fact that many previous studies have relied on Fst statistics inferred from allozyme data, which may be an unreliable estimator of actual gene flow (Whitlock \& McCauley, 1999; Wilkinson-Herbots \& Ettridge, 2004). Additionally, a lack of phylogenetic control makes it difficult to draw firm conclusions from the existing evidence. Although Kelley et al's study explicitly contrasted sister species, Peterson and Denno underscored that the heterogeneity of individual studies grouped into the three dietbreadth classes in their study made it difficult to control for confounding variables, such as differences in the organisms' ecology, and phylogenetic and biogeographic histories.

The ideal way to resolve the existing ambiguity surrounding this issue would be to specifically estimate gene flow using coalescent-based methods, rather than relying on Fst statistics, and to more closely control for variation in habitat patchiness (or predictors thereof) and dispersal ability. Towards that end, we examined population structure in three species of cactus-feeding longhorn beetles. There are two major genera of cactus-specialists within the longhorn beetles (Cerambycidae), the flightless beetles in the genus Moneilema (Say) and the fully volant Coenopoeus (Horn). Previous research on the genus Moneilema indicated significant phylogeographic structure within and between species and indicated that topographic barriers were a significant determinant of migration rates in these flightless animals (Smith, 2003; Smith \& Farrell, 2005; Smith \& Farrell, In Press-a; Smith \& Farrell, In Press-b). Here we examine genetic diversity in the longhorn cactus beetle Coenopoeus palmeri LeConte using coalescent-based estimates of migration rates, and compare these results with two previous studies of population structure in the flightless Moneilema cactus beetles $M$. gigas LeConte and $M$. appressum LeConte.

Because of their exceedingly similar host and habitat use, these three species provide a uniquely well-controlled natural experiment in which to examine the ecological factors that determine levels of gene flow. M. appressum and $C$. palmeri occur in sympatry in semidesert grasslands and mixed forest in the border regions of the southwestern United States and northwestern Mexico, and are nearly identical in their natural history and

\begin{tabular}{|l|lll|}
\hline & Journal : GENE & Dispatch : 27-7-2005 & Pages : 12 \\
CMS No. : DO00020714 & $\square$ LE & $\square$ TYPESET \\
MS Code: GENE 104R1 & $\nabla$ CP & $\square$ DISK \\
\hline
\end{tabular}


169 ecology. Both species feed on Opuntia cacti as

170 adults, and the larvae burrow inside the stems of

171 these cacti until they pupate and later emerge as

172 adults during the mid-summer monsoon rains.

173 Additionally, both $M$. appressum and C. palmeri

174 occur primarily in fragmented habitats in mid-

175 elevation grassland and mixed-forest communities,

176 feeding on two sister species of cacti, $O$. spinosior

177 and $O$. imbricata (but see Lingafelter (2003) for

178 noteworthy exceptions). In contrast, M. gigas, al-

179 though also a cactus specialist, feeds on a wide

180 variety of prickly pear and cholla cacti, has been

181 reported from a number of other non-Opuntia

182 cacti (Crosswhite \& Crosswhite, 1985), and has a

183 continuous range that includes a variety of low

184 and mid-elevation habitats from tropical decidu-

185 ous forests through desert scrub and semi-desert

186 grasslands (Raske, 1966).

187 Here, we examine population structure in these

188 three species using mitochondrial DNA (mtDNA)

189 sequence data and coalescent-based methods to

190 infer migration rates. We then use analyses of

191 covariance to evaluate the relative contributions of

192 dispersal ability, diet breadth, and habitat

193 distribution in determining population structure.

\section{Materials and methods}

\section{Insect collections}

196 Specimens of Moneilema and Coenopoeus were

197 collected in Arizona, New Mexico, and Sonora,

198 Mexico, during the summers of 1998-2000 (See

199 Table 1). Collection localities were identified by

200 referring to published records (Linsley \& Chem-

201 sak, 1984), museum collections, and biotic com-

202 munities maps (Brown, 1994; Brown,

203 Reichenbacher \& Franson, 1998). Specimens were

204 collected by hand and preserved in $100 \%$ ethanol.

205

206

207

208

209

210

211

212

213

\section{Genetic data}

Specimens were selected for sequencing to obtain representative samples from across the species' range. Whole genomic DNA was extracted using the salting-out procedure described by Sunnucks and Hales (1996). PCR and thermal cycle sequencing were used to amplify and sequence $c a$. $790 \mathrm{bp}$ of the mitochondrial Cytochrome Oxidase One (COI) gene, corresponding to positions 2183

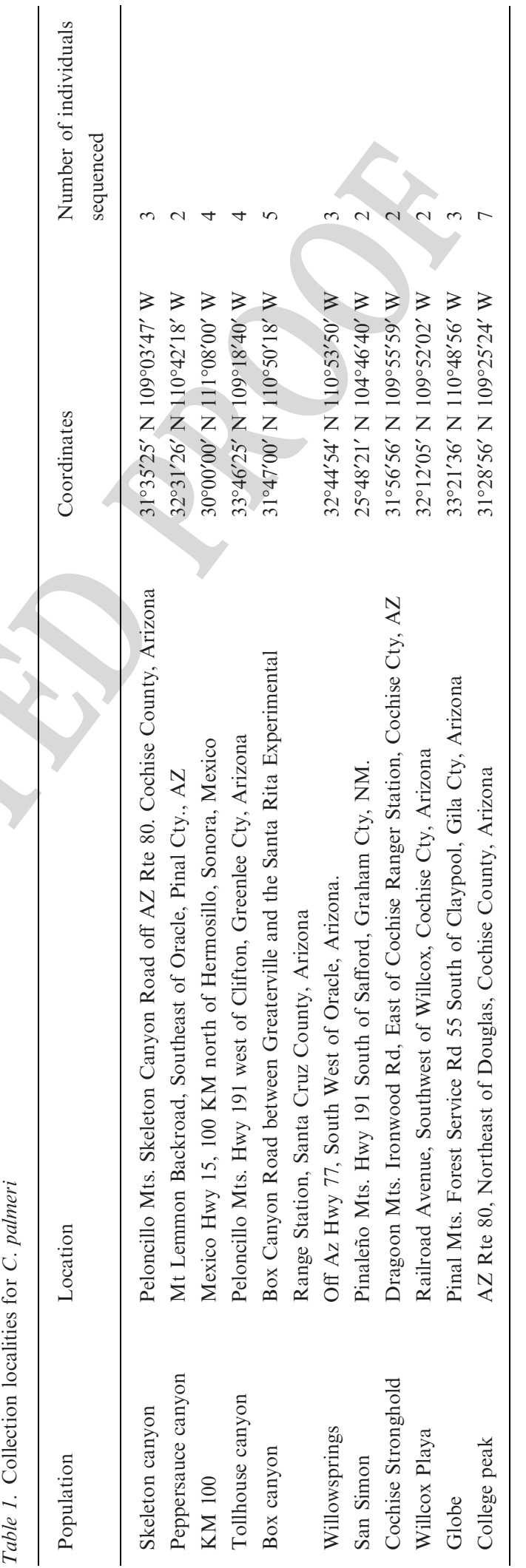

\begin{tabular}{|l|lll|}
\hline & Dournal : GENE & Dispatch : 27-7-2005 & Pages : 12 \\
CMS No. : DO00020714 & $\square \quad L E$ & $\square$ TYPESET \\
MS Code: GENE 104R1 & $\square$ CP & $\square$ DISK \\
\hline
\end{tabular}


214 to 2963 of the Drosophila yakuba mitochondrial

215 genome. PCR conditions and DNA sequencing

216 protocols are described in Smith (2003), Smith and

217 Farrell (2005), and Smith and Farrell (In Press-b).

218 Primer sequences used for PCR and sequencing

219 are described in Farrell (2001)

220 DNA sequence data were assembled in

221 Sequencher version 4.1 (Gene Codes Corporation,

222 Ann Arbor Michigan), and easily aligned by eye

223 using MacClade vers. 4.03 (Maddison \&

224 Maddison, 2001).

\section{Coalescent analyses}

Per generation migration rates in $C$. palmeri were estimated using the same procedures described by Smith and Farrell (2005) and Smith and Farrell (In Press-b) to estimate migration rates in $M$. appressum and $M$. gigas. That is, symmetric, pergeneration rates of migration between all pairs of populations were estimated using the MDIV program developed by Rasmus Nielsen to implement models of the coalescent process described by Nielsen and Wakeley (2001). Migration rates were expressed as the parameter ' $M$ ', equal to the average number of migrants moving between two populations per generation. In order that estimated migration rates would be maximally comparable to those previously estimated for $M$. appressum and $M$. gigas, a priori maximum migration rates and divergence times were the same as those described in the previous studies $\left(M_{\max }=3, T_{\max }=10\right)$ and the solution space was explored using a three million generation Markov Chain Monte Carlo (MCMC) with a five hundred thousand generation burn-in using a finite sites model of evolution.

In order to explore aspects of demographic history in this species that could potentially influence estimates of gene flow, divergence times between demes were also calculated using MDIV, and the coalescent-scaled parameter ' $T$ ' was converted to years as follows:

$$
T_{\mathrm{div}}=T \Theta /(2 \mu)
$$

where $\mu$ is equal to the expected number of mutations that will occur in a sample of $n$ base pairs per generation. In this case we assumed one generation per year (Linsley \& Chemsak, 1984), and used the maximum likelihood estimate of $\mathrm{P}$ $(=2 \mathrm{Ne} \mu)$ calculated from MDIV. The neutral mutation rate was assumed to be $1.5 \%$ per million years, based on a calibration for the closely related Tetraopes milkweed beetles (Farrell, 2001).

Likewise, in order to test for deviations from a standard coalescent model that might bias estimates of migration rates, such as exponential population growth or natural selection, Tajima's $D$ was calculated in Arlequin (Schneider, Rosselli \& Excoffier, 2000), and compared to $D$ computed from 1000 simulated data sets.

\section{Biogeographic variables}

In order to examine the effects of distance and habitat distribution on migration rates, the distance between collection localities and the relative 'patchiness' of available habitat were calculated. Great circle distances between collection localities were calculated from GPS coordinates using the program EarthDistances (Byers, 1999), and were compiled into a distance matrix. Habitat patchiness was quantified by identifying biotic communities in which each insect species is known to occur, and a biotic communities map (Brown, 1994) was used to determine whether two collection localities were connected by contiguous areas of suitable habitat for a given species. If a particular species could pass between two localities, traveling in a straight line, without having to traverse habitat where no suitable hosts occur, then these localities were considered contiguous. Conversely, if a particular species, traveling in a straight line between two particular localities, would have to pass areas communities without suitable hosts, these two populations were considered to be non-contiguous. On this basis, a matrix of pair-wise contrasts between collection localities was created for each species, corresponding to the level of connectivity between each pair of localities; contrasts between contiguous localities were assigned a score of one (1), contrasts between non-contiguous localities were assigned a score of zero (0). This matrix is available from the authors upon request.

\section{Statistical analyses}

Correlations of migration rates with geographic distance between populations within species were calculated using a Mantel test implemented in FSTAT version 2.9.3.2 (Goudet, 2002) using

\begin{tabular}{|l|lll|}
\hline & Journal : GENE & Dispatch : 27-7-2005 & Pages : 12 \\
CMS No. : DO00020714 & $\square$ LE & $\square$ TYPESET \\
MS Code: GENE 104R1 & $\nabla$ CP & $\square$ DISK \\
\hline
\end{tabular}


30920,000 permutations each. The effect of habitat

310 patchiness on migration rates within species was

311 examined using a partial Mantel test to examine

312 residual variation in migration rates after the effect

313 of distance had been removed.

314 Following Peterson and Denno (1998) analyses

315 of covariance were used to examine the effects of

316 dispersal ability and habitat patchiness on gene

317 flow, while controlling for the confounding effect

318 of distance. Dispersal ability was coded as a cate-

319 gorical variable, with each species coded as either

320 flightless (0) or flight-capable (1); migration rates

321 and biogeographic variables were calculated as

322 described above. Analyses of covariance were

323 executed in Statistica version 6.0 (Stat Soft, Inc.

324 Tulsa OK), and the distance-corrected, mean val-

325 ues of the parameter ' $M$ ' for each category were

326 computed using a least-squares method. with the highest divergence times being between populations separated by the largest geographic distance. However, examination of the posterior distributions suggests that for most contrasts the divergence times were not statistically different from zero. Tajima's $D$ statistic was equal to -0.06956 ; based on 1000 simulated data sets, this value is not significantly different from zero $(p=0.5390)$.

Mantel and partial Mantel tests of migration rates within species were significantly correlated with the distance between populations across all three species $(p<0.01)$ (See Figure 1), but there was no evidence that habitat patchiness significantly decreased migration rates when correcting for distance using a partial Mantel test. For $C$. palmeri and $M$. gigas the effects of habitat patchiness were non-significant $(p=0.4135 n=55$ and $p=0.0815 n=231$, respectively), and for $M$. appressum there was marginally significant, negative correlation between habitat patchiness and distance-corrected migration rates $(p=0.0227$ $n=91$ ). That is, demes connected by areas of potential habitat had lower (distance corrected) migration rates than demes separated by inhospitable habitats.

In the interspecific comparisons using analysis of covariance, although migration rates were significantly influenced by flight ability $(p<0.001$, $n=377$ ) (see Figure 2 and Table 3), there was no significant difference in migration rates based on habitat patchiness $(p=0.395)$ Neither did the two species of flightless beetles differ in average migration rates $(p=0.214, n=322)$ (see Table 4) despite the differences in habitat connectivity between populations in these two species.

Table 2. Migration rates between populations in C. palmeri

\begin{tabular}{llllllllllll}
\hline KM 100 & & 129973 & 159269 & 340917 & 455979 & 199558 & 369090 & 553014 & 242812 & 130696 & 672914 \\
Box canyon & 2.76 & & 23300 & 86253 & 96980 & 80723 & 83966 & 97957 & 246481 & 73603 & 216539 \\
Willowsprings & 1.026 & 2.922 & $/$ & 123507 & 77929 & 80723 & 56893 & 158060 & 175409 & 21107 & 53333 \\
Peppersauce & 0.438 & 1.098 & 1.428 & $/$ & 8160 & 35375 & 2666 & 24806 & 1076 & 363262 & 298307 \\
Globe & 0.168 & 1.896 & 2.262 & 2.79 & $/$ & 139122 & 92777 & 73315 & 120317 & 450626 & 516539 \\
Cochise stronghold & 0.894 & 2.64 & 1.662 & 1.602 & 2.028 & $/$ & 164075 & 65691 & 54817 & 5880 & 173904 \\
Willcox & 0.456 & 1.068 & 1.278 & 2.988 & 1.572 & 0.834 & $/$ & 739 & 2211 & 396430 & 509460 \\
San Simon & 0.21 & 1.092 & 0.708 & 1.35 & 1.626 & 1.35 & 1.782 & $/$ & 3215 & 415580 & 311578 \\
Tollhouse & 0.198 & 0.246 & 0.522 & 2.88 & 0.498 & 0.654 & 1.182 & 2.868 & $/$ & 292019 & 92207 \\
Skeleton canyon & 0.546 & 1.098 & 0.48 & 0.042 & 0.186 & 3 & 0.09 & 0.06 & 0.054 & $/$ \\
College peak & 0.048 & 0.606 & 1.5 & 0.3 & 0.252 & 0.81 & 0.348 & 0.3 & 0.246 & 2.928 & $/$ \\
\hline
\end{tabular}

\begin{tabular}{|l|lll|}
\hline & Journal : GENE & Dispatch : 27-7-2005 & Pages : 12 \\
CMS No. : DO00020714 & $\square$ LE & $\square$ TYPESET \\
MS Code: GENE 104R1 & $\nabla$ CP & $\square$ DISK \\
\hline
\end{tabular}



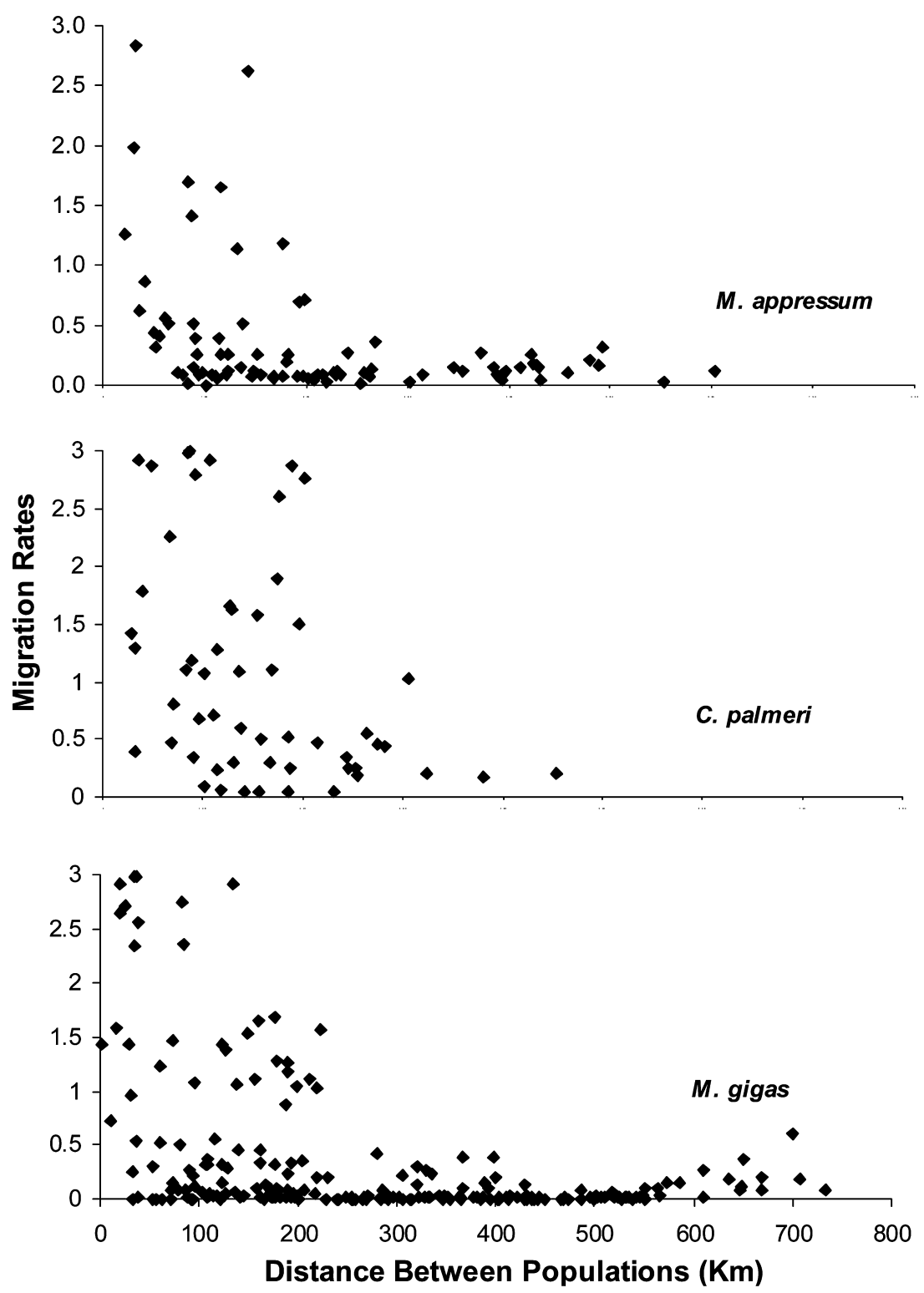

Figure 1. Effect of distance between localities on symmetric, per generation migration rates (M) in M. appressum, C. palmeri, and M. gigas.

\section{Discussion}

These results suggest that the populations of $C$. palmeri sampled in this study are experiencing high rates of ongoing gene flow, and that, despite an isolation-by-distance effect, the data did not differ significantly from expectations under a simple coalescent model. These results differ markedly from biogeographic patterns found in the sympatrically distributed $M$. appressum (Smith and
Farrell, In Press-b), where there was evidence that 387 topographic variation presented a significant bar- $\quad 388$ rier to dispersal, and that populations separated by 389 major river valleys were genetically isolated. $\quad 390$

Across species, statistical comparisons reveal 391 highly significant difference in migration rates be- 392 tween the flight-capable Coenopoeus palmeri, and 393 the two flightless Moneilema species. Although it 394 would be ideal to be able to compare sister species, 395 as in the Kelley et al. (2000) study, it is rarely 396

\begin{tabular}{|l|lll|}
\hline & Journal : GENE & Dispatch : 27-7-2005 & Pages : 12 \\
CMS No. : DO00020714 & $\square$ LE & $\square$ TYPESET \\
MS Code : GENE 104R1 & $\varangle$ CP & $\square$ DISK \\
\hline
\end{tabular}




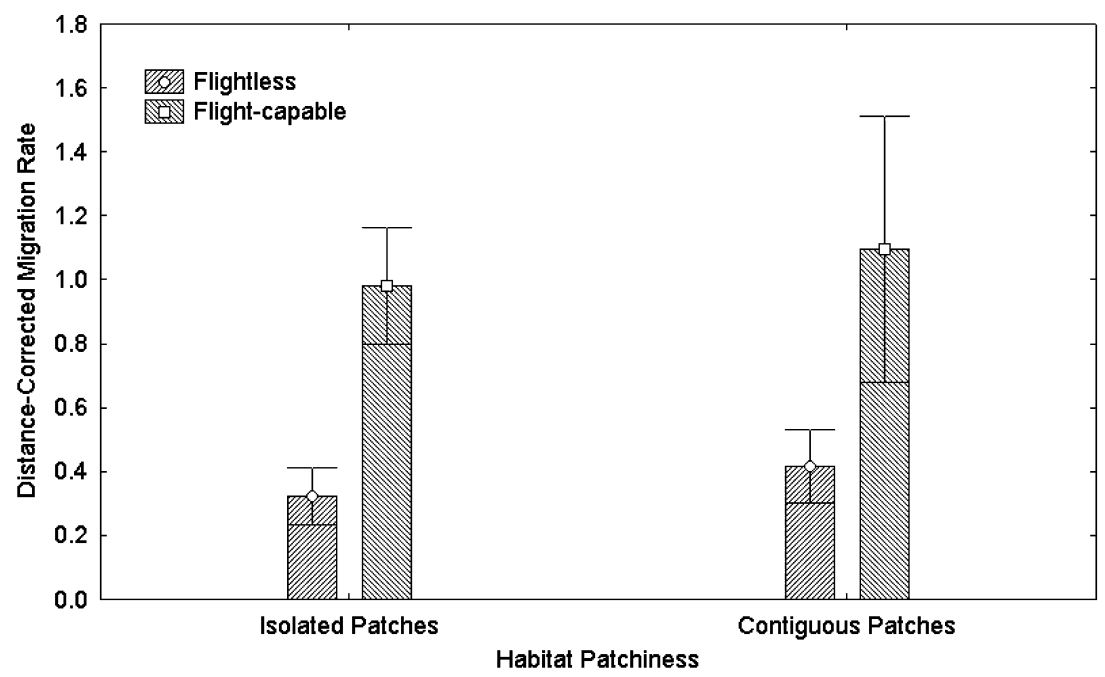

Figure 2. Distance-corrected migration rates between isolated and contiguous habitat patches in flightless $(n=322$ pair wise contrasts) and flight-capable species ( $n=55$ pair wise contrasts). Migration rates are shown as least-squares means; error bars show the $95 \%$ confidence intervals. The effect of flight ability on migration rates is highly significant $(p<0.001)$, the effect of habitat patchiness is not $(p=0.395)$.

possible in natural systems to find contrasts that control for all variables, particularly because sister taxa almost always differ in distribution or host preference. In this case, the remarkable similarity in the ecology of $M$. appressum and $C$. palmeri

Table 3. Analysis of covariance across all taxa $n=377$

\begin{tabular}{lrrrrr}
\hline Effect & $\begin{array}{l}\text { Sum of } \\
\text { squares }\end{array}$ & $\begin{array}{l}\text { Mean } \\
\text { squares }\end{array}$ & $F$ & $P$ \\
\hline Distance & 23.01 & 23.01 & 58.85 & $<0.001^{*}$ \\
Flight & 11.56 & 11.56 & 29.57 & $<0.001^{*}$ \\
Habitat patchiness & 0.28 & 0.28 & 0.73 & 0.395 \\
Flight $\times$ Habitat & 0.00 & 0.00 & 0.01 & 0.925 \\
Patchiness & & & & \\
\hline
\end{tabular}

Table 4. Analysis of covariance within Moneilema $n=322$

\begin{tabular}{lrrrr}
\hline Effect & $\begin{array}{r}\text { Sum of } \\
\text { squares }\end{array}$ & $\begin{array}{l}\text { Mean } \\
\text { squares }\end{array}$ & & \multicolumn{2}{l}{$P$} \\
\hline Distance & 15.72 & 15.72 & 50.38 & $<0.001^{*}$ \\
Species & 0.48 & 0.48 & 1.55 & 0.214 \\
Habitat Patchiness & 0.01 & 0.01 & 0.04 & 0.838 \\
Species*Habitat & 0.88 & 0.88 & 2.83 & 0.093 \\
Patchiness & & & & \\
\hline
\end{tabular}

allows us to examine dispersal ability directly with a precision that is not generally possible in sister-group comparisons.

In contrast, there was almost no difference attributable to the relative patchiness of habitats. Whereas the strong effect of dispersal ability on migration rates was expected, it is noteworthy that there was almost no reduction in migration rates due to the patchiness of habitat distributions, neither across taxa nor within species. These data suggest that, contrary to other recent studies (Dobler \& Farrell, 1999; Kelley et al., 2000) the changes in population structure that accompany specialization may have only minor effects on the rate of genetic divergence between populations, at least in these desert insects. Instead, extrinsic factors such as barriers to dispersal and demographic history may be more important in determining genetic variation within and between populations in these groups.

It is unclear, however, to what extent this finding would hold true for other groups of phytophagous insects. Whereas migration rates in the two flightless species may be inherently low, and hence the additional reductions in gene flow due to habitat patchiness may be insignificant, within Coenopoeus palmeri the absence of an effect of habitat patchiness on migration rates may reflect the spatial scale of the study.

\begin{tabular}{|l|lll|}
\hline & Journal : GENE & Dispatch : 27-7-2005 & Pages : 12 \\
CMS No. : DO00020714 & $\square$ LE & $\square$ TYPESET \\
MS Code : GENE 104R1 & $\varangle$ CP & $\square$ DISK \\
\hline
\end{tabular}


It is also worth considering what effect sample size may have had on estimates of migration rates. Unfortunately, local population density is highly variable in cactus beetles, and consequently for some demes only a very small number of individuals were collected. It is unlikely, however, that the small sample sizes for these populations biased the overall results. Although it is possible that migration rates may not be estimated accurately for populations that included only a few individuals, and that this in turn may have introduced some noise into the analysis, small sample sizes should not have biased the study towards rejecting the null hypothesis of no difference in migration rates between flightless and volant species. Indeed, using simulations to examine deviations from the standard coalescent, Sjodin et al. (2005) showed that for extremely small sample sizes population structure is overestimated, suggesting that if small sample sizes had biased this study we would have been unable to reject the null hypothesis. The highly significant difference in migration rates between flightless and winged species is therefore a strong indication that sample sizes did not zintroduce statistical bias.

Finally, it seems reasonable to explore the consequences of the microevolutionary phenomena seen here on macroevolutionary patterns in general. Habitat patchiness due to host specialization is often identified as one factor that may have occasioned the startling diversity of phytophagous insects (Futuyma \& Moreno, 1988; Farrell, 1998). Given that the data presented here suggest that dispersal ability may be much more important in determining population structure and the potential for local demes to diverge through genetic drift, it seems fair to consider whether lineages with inherently low capacity for dispersal might be more prone to speciation and hence more diverse. Alternatively, groups with low intrinsic rates of dispersal might be more prone to extinction; the infrequency of immigration makes it more likely that small populations will die out, and low levels of gene flow could make it more difficult for beneficial mutations to spread throughout a metapopulation.

Although hypotheses about the relative diversity of different groups are best addressed using a phylogenetic approach that control differences in the age of groups, such as contrasts between sister groups (Mitter, Farrell \& Wiegmann, 1988), comprehensive phylogenetic information is rarely available for studies that would consider an entire fauna. An approach that has been used for this purpose in the past is the comparison of species/ genus ratios (Carlquist, 1974; Peck, Wigfull \& Nishida, 1999). As a preliminary investigation of the consequences of dispersal ability for diversification rates, we surveyed the literature to quantify the diversity of cactus-feeding insects in North America and then compared the average number of species per genus in groups that were either primarily, or entirely flightless with those where flight was well-developed. We excluded species that were primarily associated with necrotic tissue - host fidelity in these might not be comparable to that of true herbivores (Mann, 1969), - species that occurred exclusively in South America - this fauna is not as well known, and likely omits many undescribed species (Mann, 1969; Zimmerman \& Granata, 2002), - and species where host records were doubtful. This comparison suggests that among the 30 genera of cactus feeding insects found in North America, the three sedentary groups are significantly more diverse $(p<0.001)$, comprising $42 \%$ of the 118 described species (see Table 5 and Figure 3).

This comparison does not take into account the relative age of the different groups, so time cannot be ruled out as an alternative explanation, but the fact that all of these taxa are cactus specialists obviously imposes a natural upper limit on their ages of origin, and there is no reason to think that flightless groups should be older than the other genera included in this contrast. Indeed, given that flightless species may be more prone to extinction, we should expect that flightless groups should be generally younger. However, as with any retrospective study, the correlation between dispersal ability and species does not necessarily imply causation. It is therefore possible that some common cause may underlie the observed pattern. For example, if flightlessness represents an adaptation to cactus feeding, then older groups, that have a longer history of cactus association over macroevolutionary time, might be more likely to have become flightless and might also have had greater opportunity to diversify.

Nevertheless, together these findings do seem to suggest that dispersal ability may play an important, and as yet under-appreciated role in shaping evolutionary patterns on a variety of time scales.

\begin{tabular}{|l|lll|}
\hline & Journal : GENE & Dispatch : 27-7-2005 & Pages : 12 \\
CMS No. : DO00020714 & $\square$ LE & $\square$ TYPESET \\
MS Code: GENE 104R1 & $\nabla$ CP & $\square$ DISK \\
\hline
\end{tabular}


Table 5. Taxonomic distribution, diversity, and dispersal ability of North American, cactus-feeding insects

\begin{tabular}{|c|c|c|c|c|c|}
\hline Order & Family & Genus & Dispersal & $\begin{array}{l}\text { \# Cactophagus } \\
\text { species in NA }\end{array}$ & References \\
\hline Coleoptera & Anobiidae & Tricorynus & Vagile & 1 & (Mann, 1969) \\
\hline Coleoptera & Cerambycidae & Archlagocheirus & Vagile & 1 & (Mann, 1969) \\
\hline Coleoptera & Cerambycidae & Coenopoeus & Vagile & 2 & (Mann, 1969; Blackwelder, 1982) \\
\hline Coleoptera & Cerambycidae & Moneilema & Sedentary & & (Raske, 1966; Linsley \& Chemsak, 1984) \\
\hline Coleoptera & Chrysomelidae & Diabrotica & Vagile & 1 & (Badii \& Flores, 2001) \\
\hline Coleoptera & Chrysomelidae & Disonycha & Vagile & 1 & (Mann, 1969) \\
\hline Coleoptera & Curculionidae & Cactophagus & Vagile & 3 & (Mann, 1969; Badii \& Flores, 2001) \\
\hline Coleoptera & Curculionidae & Cylindrocopturus & Vagile & 2 & $\begin{array}{l}\text { (Mann, 1969; Badii \& Flores, 2001; } \\
\text { Zimmerman \& Granata, 2002) }\end{array}$ \\
\hline Coleoptera & Curculionidae & Gerstaeckeria & Sedentary & 28 & (Mann, 1969; O’Brien, 1969; Blackwelder, 1982) \\
\hline Coleoptera & Curculionidae & Onychobaris & Vagile & 1 & (Mann, 1969) \\
\hline Coleoptera & Scarabaeidae & Phyllophaga & Vagile & 1 & (Badii \& Flores, 2001) \\
\hline Diptera & Cecidomyiidae & Asphondylia & Vagile & 3 & (Mann, 1969; Zimmerman \& Granata, 2002) \\
\hline Diptera & Cecidomyiidae & Mayetolia & Vagile & 3 & (Mann, 1969) \\
\hline Diptera & Cecidomyiidae & Neolasioptera & Vagile & 1 & (Mann, 1969) \\
\hline Diptera & Lonchaeidae & Dasiops & Vagile & 1 & (Mann, 1969) \\
\hline Hemiptera & Capsidae & Hesperolabops & Vagile & 1 & (Mann, 1969; Oliveira et al., 1999; Badii \& Flores, 2001) \\
\hline Hemiptera & Coreidae & Chelinidea & Vagile & 5 & $\begin{array}{l}\text { (Mann, 1969; Herring, 1980; Badii \& Flores, 2001; } \\
\text { Zimmerman and Granata, 2002) }\end{array}$ \\
\hline Hemiptera & Coreidae & Leptoglossus & Vagile & 2 & (Mann, 1969; Mendez et al., 2004) \\
\hline Hemiptera & Coreidae & Narnia & Vagile & 3 & (Mann, 1969; Zimmerman \& Granata, 2002) \\
\hline Homoptera & Dactylopiidae & Dactylopius & Sedentary & & $\begin{array}{l}\text { (Mann, 1969; Perez Guerra \& Kosztarab, 1992; } \\
\text { Badii \& Flores, 2001; Zimmerman \& Granata, 2002) }\end{array}$ \\
\hline Homoptera & Diaspididae & Diaspidae & Sedentary & & (Mann, 1969; Zimmerman and Granata, 2002) \\
\hline Lepidoptera & Gelechiidae & Aerotypia & Vagile & 1 & (Mann, 1969) \\
\hline Lepidoptera & Gelechiidae & Metapleura & Vagile & 1 & (Mann, 1969) \\
\hline Lepidoptera & Gracilariidae & Marmara & Vagile & 1 & (Mann, 1969) \\
\hline Lepidoptera & Phycitidae & Alberada & Vagile & 2 & (Mann, 1969) \\
\hline Lepidoptera & Phycitidae & Cactobrosis & Vagile & 5 & (Mann, 1969; Fleming \& Holland, 1998) \\
\hline Lepidoptera & Phycitidae & Cahela & Vagile & 1 & (Mann, 1969) \\
\hline Lepidoptera & Phycitidae & Eremberga & Vagile & 3 & (Mann, 1969) \\
\hline Lepidoptera & Phycitidae & Melitara & Vagile & 4 & $\begin{array}{l}\text { (Mann, 1969; Wangberg \& Parker, 1981; } \\
\text { Burger \& Louda, 1994; Carlton \& Kring, 1994; } \\
\text { Solis, Hight \& Gordon, 2004) }\end{array}$ \\
\hline Lepidoptera & Phycitidae & Olycella & Vagile & 3 & $\begin{array}{l}\text { (Mann, 1969; Badii \& Flores, 2001; } \\
\text { Zimmerman and Granata, 2002) }\end{array}$ \\
\hline Lepidoptera & Phycitidae & Ozamia & Vagile & 4 & (Mann, 1969; Solis, Hight \& Gordon, 2004) \\
\hline Lepidoptera & Phycitidae & Rumatha & Vagile & 2 & (Mann, 1969; Solis, Hight \& Gordon, 2004) \\
\hline Lepidoptera & Phycitidae & Yosemitia & Vagile & 4 & (Mann, 1969; USFWS, 1993) \\
\hline Lepidoptera & Pyralidae & Laniifera & Vagile & 1 & (Badii \& Flores, 2001) \\
\hline Lepidoptera & Pyralidae & Upiga & Vagile & 1 & (Fleming \& Holland, 1998) \\
\hline Lepidoptera & Pyraustidae & Megastes & Vagile & 1 & (Mann, 1969; Zimmerman \& Granata, 2002) \\
\hline Lepidoptera & Pyraustidae & Mimorista & Vagile & 2 & (Mann, 1969; Nieman, 1991) \\
\hline Lepidoptera & Pyraustidae & Noctuelia & Vagile & 1 & (Mann, 1969) \\
\hline Lepidoptera & Tineidae & Dyotopasta & Vagile & 1 & (Mann, 1969) \\
\hline Thysanoptera & Thripidae & Sericothrips & Vagile & 1 & (Badii \& Flores, 2001; Zimmerman and Granata, 2002) \\
\hline
\end{tabular}

\begin{tabular}{|l|lll|}
\hline & Journal : GENE & Dispatch : 27-7-2005 & Pages : 12 \\
CMS No. : DO00020714 & $\square$ LE & $\square$ TYPESET \\
MS Code: GENE 104R1 & $\nabla$ CP & $\square$ DISK \\
\hline
\end{tabular}




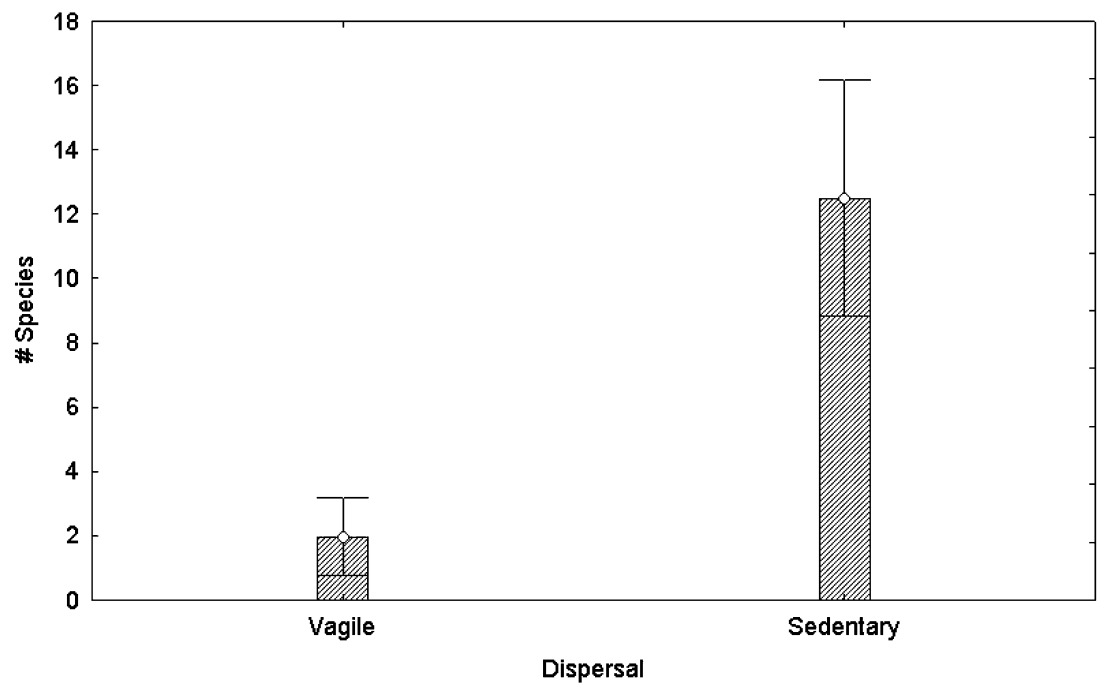

Figure 3. Least squares mean number of species per genus in sedentary and highly vagile groups of North American, cactusfeeding insects. Error bars represent $95 \%$ confidence intervals. The effect of dispersal ability on species diversity is highly significant $(p<0.001)$.

Dispersal ability has a significant impact on local population structure and gene flow over microevolutionary time, and this impact ultimately shapes macroevolutionary patterns. These results suggest, therefore, that extrinsic barriers to dispersal and gene flow be more important than ecological factors, such as diet breadth, in promoting divergence and speciation.

\section{Acknowledgements}

We wish to thank the Coronado National Forest and the Mexican Secretary of the Environment and Natural Resources for granting permission to collect insects and conduct research within their jurisdictions (USDA Permit \# 2075-01; Mexico SRE Permit \# DAN-03200; Mexico SEMARNAT Permit \# DOO 02-2916). Dr. Rick Brusca, Wendy Moore, Nelia Padilla, JohnMigue and Dylan Wilmsen, and Dr. Derrick Zwickl assisted during field collections. Molly Moore assisted with PCR and DNA sequencing for this project. Funding for this project was provided by the Putnam Expedition fund to the MCZ and the NSF doctoral dissertation improvement grant to C. I. Smith (Award \# 0073291). We are indebted to Professor Olle Pellmyr and two anonymous reviewers who provided thoughtful and constructive comments about this manuscript.

\section{References}

Antonovics, J., 1992. Towards community genetics, pp. 426 449 Plant Resistance to Herbivores and Pathogensin edited by R.L. Fritz \&E.L. Simms. University of Chicago Press, Chicago.

Avise, J.C., 1994. Molecular Markers, Natural History and Evolution. Chapman and Hall, New York.

Badii, M.H. \& A.E. Flores, 2001. Prickly pear cacti pests and their control in Mexico. Florida Entomologist 84: 503505 .

Blackwelder, R.E., 1982. Checklist of the Coleopterous Insects of Mexico, Central America, The West Indies and South America, 1982 edition. Smithsonian Institution, Washington, D.C.

Brown, D., 1994. Biotic Communities. University of Utah Press, Southwestern United States and Northwestern Mexico.

Brown, D.E., F. Reichenbacher \& S.E. Franson, 1998. Classification of North American Biotic Communities. University of Utah Press, Salt Lake City.

Burger, J.C. \& S.M. Louda, 1994. Indirect versus direct effects of grasses on growth of a cactus (Opuntia fragilis) - Insect herbivory versus competition. Oecologia 99: 79-87.

Byers J.A., 1999. Great circle distance calculated between points on earth given latitude and longitude. Western Cotton Research Lab.

Carlquist, S.J., 1974. Island Biology. Columbia University Press, New York.

\begin{tabular}{|l|lll|}
\hline & Journal : GENE & Dispatch : 27-7-2005 & Pages : 12 \\
CMS No. : DO00020714 & $\square$ LE & $\square$ TYPESET \\
MS Code : GENE 104R1 & $\varangle$ CP & $\square$ DISK \\
\hline
\end{tabular}


Carlton, C.E. \& T.J. Kring, 1994. Melitara prodenialis Walker on prickly pear in arkansas. Southwestern Entomologist 19: 23-31.

Collins, J., 2003. What can we learn from community genetics? Ecology 84: 574-576.

Crosswhite, C. \& F. Crosswhite, 1985. Trichocerues as a potential nursery crop in southern Arizona, with discussion of the Opuntia borer (Cerambycidae: Moneilema gigas) as a serious threat to its cultivation. Desert Plants 7: 195-203.

Dobler, S. \& B.D. Farrell, 1999. Host use evolution in Chrysochus milkweed beetles: evidence form behavior, population genetics and phylogeny. Molecular Ecology 8: 1297-1307.

Dobzhansky, T., 1937. Genetics and the Origin of Species. Columbia University Press, New York.

Farrell, B.D., 1998. Inordinate fondness explained: why are there so many beetles?. Science 281: 555-559.

Farrell, B.D., 2001. Evolutionary assembly of the milkweed fauna: Cytochrome Oxidase I and the age of Tetraopes beetles. Molecular Phylogenetics and Evolution 18: 467478.

Farrell, B.D. \& C. Mitter, 1994. Adaptive radiation in insects and plants: time and opportunity. American Zoologist 34: 57-69.

Fleming, T.H. \& J.N. Holland, 1998. The evolution of obligate pollination mutualisms: senita cactus and senita moth. Oecologia 114: 368-375.

Futuyma, D.J., 1987. On the role of species in anagenesis. The American Naturalist 130: 465-473.

Futuyma, D.J. \& G. Moreno, 1988. The evolution of specialization. Annual Review of Ecology and Systematics 19: 207-233.

Goudet J., 2002. FSTAT, version 2.9.3.2. Institute of Ecology, UNIL.

Herring, J., 1980. Review of the cactus bugs of the genus Chelinidea with the description of a new species (Hemiptera, Coreidae). Proceedings of the Entomological Society of Washington 82: 237-251.

Kelley, S.T., B.D. Farrell \& J. Mitton, 2000. Effects of specialization on genetic differentiation in sister species of bark beetles. Heredity 84: 218-227.

Liebherr, J.K., 1988. Gene flow in ground beetles (Coleoptera: Carabidae) of differing habitat preference and flight-wing development. Evolution 42: 129-137.

Lingafelter, S., 2003. New host and elevational records for Moneilema appressum (Coleoptera: Cerambycidae). Journal of the New York Entomological Society 111: 51-56.

Linsley E.G. \& Chemsak J.A., 1984. The Cerambycidae of North America, Part VII, No 1: Taxonomy and Classification of the subfamily Lamiinae, tribes Parmenini through Acanthoderini. University of California Press, Berkeley.

Maddison, W.P. \& D. Maddison, 2001. MacClade. 4.03. Sinauer Associates, Sunderland, MASS.

Mann, J., 1969. Cactus-Feeding Insects and Mites. Smithsonian Institution, Washington, DC.

Mayr, E., 1942. Systematics and the Origin of Species. Harvard University Press, Cambridge.

Mayr, E., 1963. Animal Species and Evolution. Harvard University Press, Cambridge.
Mendez, M., R. Duran, I. Olmsted \& K. Oyama, 2004. Population dynamics of Pterocereus gaumeri, a rare and endemic columnar cactus of Mexico. Biotropica 36: 492-504.

Mitter, C., B. Farrell \& B. Wiegmann, 1988. The phylogenetic study of adaptive zones: has phytophagy promoted insect diversification?. The American Naturalist 132: 107128.

Morin, P.J., 2003. Community ecology and the genetics of interacting species. Ecology 84: 577-580.

Nielsen, R. \& J. Wakeley, 2001. Distinguishing migration from isolation: a Markov Chain Monte Carlo approach. Genetics 158: 885-896.

Nieman, E., 1991. The Introduction of Mimorista pulchellalis (Lepidoptera, Pyraustidae) into South-Africa for the Biological-Control of Jointed Cactus, Opuntia-Aurantiaca. 1. Biology and Mass-Rearing Techniques. Entomophaga 36: 69-76.

O'Brien, C.W., 1969. A taxonomic revision of the genus Gerstaeckeria North of Mexico (Coleoptera: Curculionidae). Annals of the Entomological Society of America 63: 255-272.

Oliveira, P.S., V. Rico-Gray, C. Diaz-Castelazo \& C. CastilloGuevara, 1999. Interaction between ants, extrafloral nectaries, and insect herbivores in Neotropical coastal sand dunes: herbivore deterrence by visiting ants increases fruit set in Opuntia stricta (Cactaceae). Functional Ecology 13: 623-631.

Peck, S.B., P. Wigfull \& G. Nishida, 1999. Physical correlates of insular species diversity: the insects of the Hawaiian Islands. Annals of the Entomological Society of America 92: 529536.

Perez Guerra, G. \& M. Kosztarab, 1992. Biosystematics of the Family Dactylopiidae (Homoptera: Coccinea) with Emphaisis on the Life Cycle of Dactylopius coccus. Viriginia Agricultural Experiment Station, Virginia Polytechnic Institute and State University, Blacksburg, Virginia.

Peterson, M.A. \& R.F. Denno, 1998. The influence of dispersal and diet breadth on patterns of genetic isolation by distance in phytophagous insects. The American Naturalist 152: 428-446.

Raske, A.G., 1966. Taxonomy and Bionomics of the Genus Moneilema (Coleoptera: Cerambycidae). $\mathrm{PhD}$ Thesis. University of California, Berkeley.

Roderick, G.K., 1996. Geographic structure of insect populations: gene flow, phylogeography, and their uses. Annual Reviews in Entomology 41: 325-52.

Schneider, S., D. Rosselli \& L. Excoffier, 2000. Arlequin vers. 2.000: A software for population genetics analysis. Genetics and Biometry Laboratory, University of Geneva.

Slatkin, M., 1985. Gene flow in natural populations. Annual Review of Ecology and Systematics 16: 393-430.

Slatkin, M., 1987. Gene Flow and the Geographic Structure of Natural Populations. Science 236: 787-792.

Smith, C.I., 2003. The Evolution of the Longhorn Cactus Beetles Moneilema Say (Coleoptera: Cerambycidae) and the Biogeographic History of the North American Deserts. PhD Thesis. Harvard University, Cambridge.

Smith, C.I. \& Farrell B.D., 2005. Recent range expansions in the flightless longhorn cactus beetles Moneilema gigas and M. armatum in response to Pleistocene climate changes. Molecular Ecology 14: 1025-1044.

\begin{tabular}{|l|lll|}
\hline & Journal : GENE & Dispatch : 27-7-2005 & Pages : 12 \\
CMS No. : DO00020714 & $\square$ LE & $\square$ TYPESET \\
MS Code: GENE 104R1 & $\nabla$ CP & $\square$ DISK \\
\hline
\end{tabular}


Smith C.I. \& Farrell B.D., In Press-a. Historical Biogeography of the Longhorn Cactus Beetles: The Influence of Pleistocene Climate Changes on American Desert Communities in Biodiversity and Management of the Madrean Archipelago II: Connecting Mountain Islands and Desert Seas edited by G.J. Gottfried, United States Department of Agriculture, Fort Collins, Colorado.

Smith C.I. \& B.D., Farrell In Press-b. Phylogeography of the longhorn cactus beetle Moneilema appressum Leconte (Coleoptera: Cerambycidae): Was the differentiation of the Madrean sky-islands driven by Pleistocene climate changes? Molecular Ecology.

Solis, M.A., S.D. Hight \& D.R. Gordon, 2004. Tracking the cactus moth, Cactoblastis cactorum Berg. as it flies and eats its way westward in the U.S. News of the Lepidopterists' Society 4(3): 4-7.

Strong, D.R., J.H. Lawton \& S.R. Southwood, 1984. Insects on Plants. Harvard University Press, Cambridge, MA.

Sunnucks, P. \& D.F. Hales, 1996. Numerous transposed sequences of mitochondrial cytochrome oxidase 1-11 in aphids of the genus Sitobion (Hemiptera: Aphididae). Molecular Biology and Evolution 13: 510-524.

Templeton, A.R., 2001. Using phylogeographic analyses of gene trees to test species status and processes. Molecular Ecology 10: 779-791.
Thompson, J.N. \& B.M. Cunningham, 2002. Geographic structure and dynamics of coevolutionary selection. Nature 417: 735-738.

USFWS., 1993. Cochise pincushion cactus (Coryphantha robbinsorum) recovery plan. USDI Fish and Wildlife Service, Albuquerque, NM.

Wangberg, J.K. \& T.B. Parker, 1981. New host record for the blue cactus borer (Melitara-dentata-Grote). Southwestern Naturalist 26: 440-441.

Whitlock, M.C. \& E. McCauley, 1999. Indirect measures of gene flow and migration. Fst $\neq 1 /(4 \mathrm{Nm}+1)$. Heredity 82 : $117-125$.

Wilkinson-Herbots, H.M. \& R. Ettridge, 2004. The effect of unequal migration rates on FST. Theoretical Population Biology 66: 185-197.

Wright, S., 1943. Isolation by distance. Genetics 28: 139-156.

Wright, S., 1978. Evolution and the Genetics of Populations Vol 4: Variability within and among Natural Populations. University of Chicago Press, Chicago.

Young, A., T. Boyle \& T. Brown, 1996. The population genetic consequences of habitat fragmentation for plants. Trends in Ecology and Evolution 11: 413-418.

Zimmerman, H. \& G. Granata, 2002. Insects Pests and Diseases, pp. 235-254 Cacti: Biology and Usesin edited by P.S. Nobel. University of California Press, Berkeley.

\begin{tabular}{|l|lll|}
\hline & Journal : GENE & Dispatch : 27-7-2005 & Pages : 12 \\
CMS No. : DO00020714 & $\square$ LE & $\square$ TYPESET \\
MS Code: GENE 104R1 & $\square$ CP & $\varangle$ DISK \\
\hline
\end{tabular}

